\title{
The Volume of Venture Capital Funds of Latvia and Their Financing Sources
}

\author{
Anatolijs Prohorovs \\ SIA Proks capital, Riga, Latvia
}

\begin{abstract}
The venture capital funds (VCF) financing sources of Latvia are considered in this paper. In the course of the work, a comparison was made between VCF financing sources generally used in Europe, Central and Eastern Europe (CEE) countries, and Latvia. Based on the results of questionnaire of VCF partners, an investigation of sources and structure of the capital attracted by all of the Latvian VCF was performed. In process of the investigation, the following methods were applied: questionnaire, logical constructive method, and comparative analysis. Moreover, some VCs were interviewed. As a result, it has been revealed that as little as five financing sources exist in Latvia unlike Europe, where VCF have not less than 13 financing sources, and unlike CEE countries where the funds are supported by at least eight financing sources. The average size of a VCF in Latvia is 10.8 M EUR, which constitutes 35\% of that of European VCF. Among the main reasons for a small size of Latvian VCF and a small number of types (classes) of their investors, the country's low financial appeal for VC and immaturity of some types of investors in Latvia can be mentioned. For that reason, the State has to compensate for a shortcoming of VC; as a result, the share percentage of social capital in VCF financing sources of Latvia has reached $76.2 \%$ while all VCF of Latvia are hybrid.
\end{abstract}

Keywords: venture capital fund raising, venture capital funds capital structure, venture capital funds financing sources, Latvia

\section{Introduction}

The VC raising problems are a relevant topic of research, especially under the post-crisis conditions. The VC industry seemed to start recovering after the crisis, but the positive post-crisis tendencies slowed down. Besides, some structural changes are going on within the industry-namely, the increasing complexity of attraction of VCF investors, especially with respect to early stage financing.

The reason for such a situation is that not all of the investors are ready to assume risks which were previously considered acceptable. The potential limited partners (LPs) of VCF are currently more circumspective about long-term "parting" with liquidity, the expected profit margin, and withdrawal deadlines than they used to be. Indeed, with regard to VCF and especially the funds financing early stages of development of young and innovative companies, the future prospects of specific portfolio companies are more obscure than those of the financing late stage development and particularly the investments into Private Equity (PE) funds.

Anatolijs Prohorovs, Ph.D. Candidate, Managing Partner of SIA Proks capital.

Correspondence concerning this article should be addressed to Anatolijs Prohorovs, Terbatas street 53-1, Riga, LV-1011, Latvia. E-mail: anatolijs.prohorovs@gmail.com. 
Since VC ecosystem in European and especially CEE countries is inferior to the U.S. system (in particular, due to a development delay in VC) (Lerner \& Tåg, 2012), the above-stated negative tendencies manifest themselves more distinctly. At the same time, the issue of financing projects connected with innovative development, transfer and commercialization of technologies developed by applied research and new business models - is becoming ever more pressing to European countries. In the opinion of Perez (2012), a sustainable economic growth is possible if investors re-orientate their policy towards the investments into innovations and the real economy. The early stage of VCF is one of the first steps of the "escalator", financing primarily the entrant young companies with a great potential for growth. Veugelers (2011) believes that the financial market barriers are too high for innovation projects launched by young companies. For that reason, both European agencies and the governments of specific countries are looking for some more efficient ways of supporting such financing source as VCF. There exist various forms and methods of support, influencing the attraction of VC. Depending on what specific forms and means of support are applied along with the exercised influence on the functioning and development VC industry in a specific country, the VCF capital amount, structure, and size may vary. VC investigators operating in new (EU11) and small countries of EU and CEE have not actually dwelled upon the issues of investor structure and VCF size. There exists some generalized data from European Venture Capital Association (EVCA) on the countries of CEE without data splitting over the countries and the investors with regard to $\mathrm{VC}$ and $\mathrm{PE}$ (individually). EVCA presents aggregated data on fund raising sources (investor classes) individually for VC and PE only concerning Europe as a whole; however, EVCA does not separate VC investors according to kinds of funds or finance stages. In the opinion of Cumming and Johan (2012), the issues of attraction of investors and the analysis of fund capital structure are currently one of the most important theoretical and practical issues of VC industry. The publicly available information necessary for such a kind of investigations regarding CEE countries is very scarce and in a non-classified form only; in most cases, there is total lack of such data or they are not accessible. Dörte Höppner, General Secretary of EVCA, believes that collecting reliable data is very important to enable EVCA to hold necessary comprehensive information for the analysis and formulation of proposals on VC industry development (Financial News, 2012). That's why an attempt of describing the structure and the size of VCF of Latvia will be made in this paper along with an attempt of drawing a comparison with the available data on CEE countries and European countries in general, and with some small countries of Europe. As a result of the investigation, data on the investor structure and the Latvian VCF size will be created, and the analysis of the established investor structure will be performed. This will allow one to develop a more efficient model of attracting VC investors in future. On the assumption of the importance and the significance of early stages of finance, it was exactly VCF (and not VC\&PE or PE) that was selected for the investigation of their capital structure and financing sources.

Aim, tasks, and novelty of the research (the aims do not reflect the theoretical investigation; probably it should be included and placed after the investigation methods).

The aim of the investigation: to create data on the VCF investors structure in Latvia, and perform the analysis of investor structure and the size of VCF of Latvia.

The goals of the investigation:

(1) to collect data on the investors structure of each VCF of Latvia existing as of the beginning of 2013, and on their sizes (not violating the principles of confidentiality and divulging sensitive information); 
(2) to generalize data on the Latvian VCF investors structure;

(3) to perform the analysis of Latvian VCF structure;

(4) to compare the data on the Latvian VCF investor structure with European VCF data as a whole and the data from CEE countries;

(5) to compare the data on Latvian VCF size with VCF sizes of Europe and CEE.

\section{Novelty of the Research}

The Latvian VCF investor structure is presented for the first time, as well as the share percentage of foreign investors and that of the managing factors.

\section{Methods of Research}

The methodological basis of the study is: the results of conducting survey of VCF partners, analysis of current scientific information sources, EVCA data, and the data on VCF of Latvia. Moreover, a number of other legislative, regulatory, statistical and informational materials listed in the reference list were used. The following methods were used in the study: questionnaires, logical constructive method, and comparative analysis; furthermore, VCs were interviewed.

\section{Research Organization}

To conduct a survey in various governmental and public agencies of Latvia (Ministry of Economics, the Latvian Guarantees Agency (LGA), Latvian private equity and venture capital association (hereinafter LVCA), Imprimatur Capital Fund Management company, ZGI Capital), a survey was conducted to obtain data on VCF operating in Latvia, and on the availability of any generalized or other information on the sources and structure of capital attracted by them. Total lack of any generalized information on investor structure and VCF capital was revealed; moreover, it was found that five VCF were operating at the beginning of the year 2013. The author has sent to each fund a questionnaire in a tabular form with the names of investor classes and the aggregate investments of a specific class, and then received answers by e-mail. The obtained data was compared with the available data on social capital (LGA). If there were some doubts about data accuracy, the author discussed the data with each respondent, making the data more precise. In process of preparation for questioning, consultations with two VCs experts (partners and managers of VCF management companies) were held. The survey was conducted in April-May, 2013. It embraced all the five operating VCF of Latvia, i.e., 100\% of the available ones. The private equity funds (PEF) were deliberately excluded. The questionnaire included some questions on the kinds of investors and the amounts invested by a specific kind, without any reference to the investors' names. This allowed one to generalize and structure the information (i.e., obtain sums and interest and make other manipulations with that information in a way typical to quantitative analysis), not touching upon any issues of commercial secret like names of investors of specific funds and the size of their investments. At the same time, the information received by the author is, in the opinion of funds, sensitive information as well; therefore, it was decided to entrust it to the author as a member of Board of Latvian venture capital and private equity association (LVCA) under the condition of using the information in a generalized form only. But generalized information on VC investments is exactly what is required for research and for its being used by other investigators, non-governmental and governmental agencies; therefore, the above-listed data limitations did not have any negative impact on the research quality. 


\section{Literature Review}

\section{Post-crisis Changes in VC industry}

In the opinion of Ghalbouni and Rousies (2010), VC\&PE industry is experiencing certain structural changes caused by both the crisis and, possibly, some other reasons. Cumming and Johan (2012) believe that the structural changes in $\mathrm{VC}$ industry are inevitable in order to preserve an important source of financing incipient companies characterized by a high growth rate. In turn, Jakušonoka and Prohorovs (2011) believe that, to ensure a post-crisis change of economic structure and to finance the innovation-driven growth, financing sources, including VC, are needed as well as changing the model of $\mathrm{VC}$ functioning (Jakušonoka \& Prohorovs, 2011). These two competing tendencies (the potential demand for VC and its poor availability) have an impact on VC industry and on raising funds to support it. Crisis and post-crisis changes in VC industry may manifest themselves differently in different countries. In the opinion of Cumming and Johan (2012), if VC\&PE industry is under the conditions of crisis; this primarily has a negative impact on the growth of new technological companies. A common challenge faced by European countries over the last years is the problem of attracting $\mathrm{VC}$ from private and institutional investors. This situation continues to worsen with respect to $\mathrm{VC}$ funds (Tykvová, Borell, \& Kroencke, 2012). The fund raising complexities over the last years had occurred, first of all, with respect to funds financing exactly the early stages of company development. The volume and the dynamics of rasing capital into the funds financing the early-stage development and PE funds for 2010-2012 are shown in Table 1.

Table 1

Comparison of Volumes and Dynamics of Early-Stage VCF and PE Funds Raising in CEE Countries in 2010-2012 (Growth Capital, Buyout, Mezzanine, Generalist)

\begin{tabular}{llcccc}
\hline Funds raised by fund stage focus & $\begin{array}{l}\text { Amounts in } \\
\text { thousands (2010) }\end{array}$ & $\begin{array}{c}€ \text { Amounts in } \\
\text { thousands (2011) }\end{array}$ & $\begin{array}{c}€ \text { Amounts in } \\
\text { thousands (2012) }\end{array}$ & $\begin{array}{c}€ \text { Change of investment volume } \\
\text { in \% as from 2010 to 2012 }\end{array}$ \\
\hline VCF early-stage & 90,270 & 71,020 & 24,870 & $\begin{array}{l}-72.5 \% \text { from the } \\
\text { recorded in } 2010\end{array}$ \\
PE (Growth capital, Buyout, & 461,490 & 788,350 & 637,560 & $\begin{array}{l}+38.1 \% \text { to the index recorded } \\
\text { in 2010 }\end{array}$ \\
$\begin{array}{l}\text { Mezzanine, Generalist) } \\
\begin{array}{l}\text { Capital raised in VCF early-stage } \\
\text { to capital raised to PE funds ratio }\end{array}\end{array}$ & $9.0 \%$ & $3.9 \%$ &
\end{tabular}

Note. Source: Developed by the author, EVCA Central and Eastern Europe Statistics 2011, EVCA Central and Eastern Europe Statistics 2012, and the author's calculation.

As is can be seen from Table 1, investors are ever more watchful of investments into VCF. Thereby, they reduce the amount of venture capital (Cumming \& Johan, 2012). Even in Germany, the flagship of European industry and export, VC in 2012 was characterized by such negative trends as fund-raising complexities (and, accordingly - the capital availability to potential portfolio companies), VCF focusing on investments into industries and lower-level risk companies, and investment rounds of less magnitude (Guellmann, 2013). The author believes that $\mathrm{VC}$ raising is quite relevant with respect to small countries (CEE) which are passing or have passed through the period of transitive economy (Prohorovs, 2013a). Raising VC and the VC structure proper largely depend on successful results (exit, devestment) of VCF. However, there is a variety of other factors influencing the attraction of VCF investors.

In 2013, Prohorovs (2013b) has investigated 27 factors influencing VC raising: The investigation was based on polling 19 VCs of Latvia (Prohorovs, 2013b). In the opinion of the Latvian VCs, the five main factors 
having a negative impact on raising capital into VCF of Latvia are the following ones (in order of precedence):

(1) Fund investors do not trust the fund management team due to lack of any positive experience and previous achievements;

(2) The fund raising is hampered by lack of institutional investors;

(3) There is no venture capital in Latvia that might transfer into venture funds, or, such a capital is not sufficient;

(4) Fund investors understand that it will be hard to find good projects to apply the funds;

(5) Fund investors understand that Latvia is a small market and, therefore, it will be difficult to promote a project in other European countries; at the same time, promotion in other countries will be hampered as well due to different regulations, laws, and the language.

\section{Some Factors Influencing Investor Structure, Capital Size, and VCF Success}

Lerner and Tåg (2012) believe that the regulatory environment, the maturity of financial market, the tax system, labour market regulation, and governmental Research and Development (R\&D) expenses are correlated with the activity of $\mathrm{VC}$ investors in different countries. The technology transfer policy is also important as well as the presence of international venture capital firms, since they provide for numerous advantages for the development of the country's VC ecosystem VC (Lerner \& Tåg, 2012).

Several researchers have attributed the successful development of early stages of VCF funding to the activity of informal venture capital (IVC). According to Mason, Botelho, and Harrison (2013), poor functioning of IVC makes a gap in the "escalator" of VCF funding projects: Respectively, no projects occur that are "prepared" to finance VCF. Prohorovs (2014) believes that VCF attractiveness for investors financing the initial stages of development may depend on the level of development and the activity of IVC in specific countries (Prohorovs, 2014). In the opinion of Sahlman and Richardson (2010), IVC and VCF complement each other. According to Zarutskie (2006), the most important factor for success at the early stages of financing is that the investment team includes both a serial entrepreneur and an experienced VCs (Zarutskie, 2006).

Prohorovs and Pavlyuk (2013) mark the interrelationship between the level of development of R\&D in specific countries and their attractiveness to VC investors VC (Prohorovs \& Pavlyuk, 2013).

According to Tykvová et al. (2012), there exists a positive relation between the developments of dynamic sectors of high-tech entrepreneurial ventures and the efficient VC industry.

In small countries in Europe, especially in CEE, the issues of competition between VCF's are not yet a significant problem of VC industry (Prohorovs \& Jakušonoka, 2012). However, VICO project researchers believe that VCF and PE funds compete with each other to attract investors (VICO, 2011).

In accordance with their respective studies, Cincera and Veugelersb (2013) believe that the lower rate of return in relation to risk in general, and in comparison with the United States in particular, makes it difficult to attract investments for early stages of VC in Europe. Let us consider the opinions of various investigators as to the forms and methods of state support of VC.

\section{Governmental Support of VC}

To promote the innovative development in a number of countries, the government applies various tools for promotion, therefore, acting as a VC acceleration catalyst (Hall \& Lerner, 2010; Schröder, 2009). There exist various forms and methods both of direct and indirect support of $\mathrm{VC}$ investments in EU and in a number of 
European countries. For example, tools of European investment fund (EIFs) consist, in particular, of investments into VCF (European Commission, 2012). Dębski (2010) believes that the further development of VC\&PE market in Poland may take place at the expense of financial resources allocated by EC, which will be directed to VCF through the National Fund. According to the data from Kitsing (2013) and Estonian Development Fund (2013), the Estonian State directly invests VC into some prospective innovative companies. Over the last five years, Estonian Development Fund acting jointly with private investors has invested into 19 companies. Two-thirds of them are technology start-ups. However, no information as to the fund volume and investment size is published (Kitsing, 2013; Estonian Development Fund, 2013). Schröder (2009) points out a very large difference between VC-raising opportunities in various European countries and admits that private VC may be raised not through subsidizing VCF by social capital but rather by establishing reduced tax rates for companies supported by private VC raised. According to the data from Meyer (2007), if government support is rendered, the "bottlenecks" are selected, for example, the least advantageous industries in terms of private VC-based investments and gaps in financing of seed stage for example. In line with indirect methods of promotion of VC private investors through tax exemptions, Lerner (2010) suggests that boosting the demand for VC on the part of State should be used instead of direct financing of VCF. According to Tykvová et al. (2012), State VC greatly differs from commercially-oriented VC since it fills up the financing gap in private $\mathrm{VC}$ and is largely focused on small and young companies at seed and start-up stages, frequently with a longer product development cycle and, accordingly, with a longer investment term. Moreover, the investments are made in local markets, not reaching after syndication with other types of VC (Tykvová et al., 2012). On the initiative of JEREMIE, two governmental VCF and one VCF for co-investment with BA were launched in Lithuania in 2009. Snieska and Venckuviene (2012) believe that it is very important to determine precisely, which specific small and medium-size companies are innovational and have the fast growth potential to become a project to be financed by VCF with government taking part. The research by Grilli and Murtinu (2013) shows that government-controlled VC exercises a small influence on sales growth and the increase in the number of employees in high-tech companies as compared to private VC. These authors also find a positive and statistically essential influence of syndicated investments on company sales growth with respect to both types of investors - but only if the syndicate is managed by private investors of VC. In their opinion, the government's ability to support high-tech commercial companies through direct participation in VC markets is doubtful. They believe that, should the European VC market ever need governmental support, the government intervention will be preferred through indirect support companies. In turn, Grilli and Murtinu (2013) believe that contribution to development of European high-tech entrepreneurial companies is connected not only with financial resources unavailability but possibly with lack of added value obtaining skills. According to Humphery-Jenner (2012), the properly structured governmental support of venture funds can promote innovations and VC activity. In his opinion, the properly structured schemes of state participation in VC can stimulate innovations.

According to Luukkonen, Deschryvere, and Bertoni (2013), there is no significant difference between two types of investors (state VC and IVC). Nevertheless, added value profiles differ with regard to those investor types. In particular, IVC results turn out to be much higher than those of state VC, including the development of business idea, professionalization, and commitment to exit.

Cumming and Johan (2009) point out that pre-seed funds where governmental VC participate invest into high-tech companies not more often than private VCF do. Jääskeläinen, Maula, and Murray (2007) believe as 
well that hybrid VCF are capable of solving the missing finance problems only temporarily; however, they do not solve the problems of investor quality improvement in VC industry. In their opinion, the state should apply other forms and methods of promotion of investors, experienced VC and entrepreneurs in key technological sectors as well.

In the opinion of Meyer (2007), government may give incentives to any manager of a private VCF to ensure financing of target-oriented portfolio companies. This raises a number of conceptual issues, including what kinds of support tools should be selected and which market segments should be selected to render community support. Meyer (2007) also believes that a fundamental question is that such kind of interference (where support is rendered under wrong circumstances or without any other accompanying measures) implies that the attractiveness to private capital is lost. Meyer (2007) believes that small and medium companies support programs should not be mixed up with VC, since such a support will be declined by the market and will give no result in terms of attracting private investors. In the opinion of Snieska and Venckuviene (2012), in countries characterized by small macroeconomics, such as Estonia, Latvia, and Lithuania where VC market is only in a formative stage, the role of State is vital (Snieska \& Venckuviene, 2012). At the same time, government should act as an originator only but not as a key player; otherwise, the excessive direct promotion in the form of state-owned VC may bring about negative consequences (Snieska \& Venckuviene, 2011). Cumming, Grillib, and Murtinu (2013) draw a conclusion that private-public VCF have an advantage over the wholly owned VCF. Bertoni and Tykvová (2012) come to the conclusion that, if VC is used to finance a new innovative product, the best result is provided by cooperation of public and private capital, so long as the private capital is controlled by a syndicate (Bertoni \& Tykvová, 2012). According to the investigation by Brander, Du, and Hellmann (2010), the best results are achieved if the state support is available but does not dominate at the same time. The findings of the investigation performed by Bertoni, Colombo, and Quas (2011) show that state venture capital (GVC) investments are incapable of raising private VC to young, small, and early-stage companies. Moreover, such public investment reduces the private VC's interest in investments and displaces private VC, since GVC can invest on below-market conditions as well (Bertoni, Colombo, \& Quas, 2011). Brander, Egan, and Hellmann (2010) show that the Canadian portfolio companies funded by private VCF demonstrate more successful exits and better valuations than those where state-owned VC participates. Moreover, they find that, despite the state-funded VCF activities' yielding lower results as against private VCF, they still do have a certain exercise effect. In other words, VCs are trained, since less experienced VCs come to work in VCF with public ownership as compared to those coming to private VCF, but, as a result, they finally gain experience and become high-class experts. The above-mentioned researchers believe that the success of hybrid VCF is partially achieved not due to high qualification of VCs but rather at the expense of their lobbying skills (Brander, Egan, \& Hellmann, 2010). Hall and Lerner (2010) believe that VCF procure "work" to funds financing the further stages of companies development. Accordingly, if state promotes investments into VCF, this may have a positive impact on PE funds investment volumes. In the opinion of Gadus (2012), a Slovak researcher, state must create special motivations to attract both GPs and KPs into hybrid VCF. Groh (2010) believes that VC investors select countries according to a number of criteria. They pay great attention to VCs qualification and the possibility of ensuring a deal flow. Groh (2010) believes that such an indicator as the financial market size and liquidity and IPO activity level is important but is not the main index anyway. In his opinion, public subsidies do not play any positive role either, when decisions are taken by institutional investors, since public money does not attract any private capital (Groh, 2010). 


\section{Result and Discussion}

As a result of polling of VCF of Latvia, there occurred some data on the structure of their capital and the sources of its attraction. First of all, let's examine the generalized data on VCF capital structure of Latvia. The data on capital structure and the sources of its attraction are shown in Table 2. For reference, the same table presents data on financing sources of 13 European VCF.

Table 2

Europe and Latvian Venture Capital Funds Raised by Type of Investors 2007-2011

\begin{tabular}{lllc}
\hline $\mathrm{Nr}$ & Types of investors & Europa 135 funds 2011 (\%) & Latvian venture capital funds raised (\%) \\
\hline 1 & Government agencies & 34.0 & 65.14 \\
2 & Private individuals & 14.9 & $5.88\left(8.98^{*}\right)$ \\
3 & Corporate investors & 12.1 & 4.03 \\
4 & Banks & 9.8 & 3.64 \\
5 & Fund of funds & 9.0 & \\
6 & Pension funds & 8.0 & 18.2 \\
7 & Capital markets & 5.0 & 0 \\
8 & Insurance companies & 2.6 & 0 \\
9 & Family offices & 2.1 & 0 \\
10 & Other asset managers & 1.2 & 0 \\
11 & Endowments and foundations & 0.6 & 0 \\
12 & Sovereign wealth funds & 0.3 & 0 \\
13 & Academic institutions & 0.2 & 0 \\
14 & Fund management company & No data & 3.1 \\
\hline
\end{tabular}

Notes. "Section "Fund management company" investments will be attributed to section "Private individuals". Source: EVCA Yearbook 2012 and the author's (Latvian funds), based on the Imprimature Capital Seed Fund, Imprimature Capital Start-up Fund, BaltCap Fund, ZGI Fund, 2EF Fund information and the author's calculation.

Let's consider and compare sources of capital (or investor classes) which provide VCF financing. Let's consider the most notable differences between the data on 135 European funds (EF) and Latvian VCF. Firstly, VCF of Latvia have six capital attraction sources; however, such a capital source as Fund Management Company is not stated in the list of EF. It is clear that partners of a management company cannot abstain from taking part in fund capital management as well. Therefore, it may be assumed that, as far as EF is concerned, the investments of Fund Management Company are included into the section "private individuals" or "corporate investors". Therefore, it is considered that VCF of Latvia have five investor types according to the investor structure proposed by EVCA. To draw a more accurate comparison between the investor structure of Latvian VCF and that of EF, these investments will be attributed to section "Private individuals", too. Then, as regards Latvian VCF, this value will constitute $8.98 \%$. So the conclusion may be drawn that, first of all, unlike 13 capital sources in EF (not counting any other unidentified sources), the Latvian funds have only five capital attraction sources. Eight EF investor classes which did not take part in financing Latvian VCF have provided $21 \%$ of capital for EF. Secondly, the financing share of government agencies with the Latvian VCF is twice as much as that of EF. Thirdly, the investment share of pension funds of Latvia exceeds the indices of attraction of that type of investors in EF more than twice. Fourthly, such classes of investors as Fund of funds, Capital markets, Insurance companies, Family offices, other asset managers, Endowments and foundations, Sovereign wealth funds, Academic institutions do not invest into VCF in Latvia so far. Fifthly, private investors 
in EF represent half as much — twice as much capital, and corporate investors and banks - three times as much. The investment data of Fund Management Company has not been included into financial statements of EVCA. In Latvia, VCF of Fund Management Company have invested 3.1\% of the total VCF capital into the capital of funds managed by them.

Latvia is a small country pertaining to the group of CEE countries. Therefore it would be interesting to get to know how capital sources of CEE look like, and it is also interesting to compare these data with the aggregated data of the Latvian VCF. The available data describing CEE countries allow us to consider the situation with the attraction of various classes of VC \& PE investors in CEE countries within five years from the last pre-crisis year (2007) and ending with the year 2011. Two of the five existing Latvian VCF started attracting capital in 2007 as well, and the other three - in 2010-2011. Since there were only five VCF in Latvia before 2013, the Latvian VCF were analyzed not based on annual split-up of investor attraction but according to investor classes within CVF capital structure. To make the picture more evident for the entire period of time, the author has calculated the average values (shares) of each class of investors in the VC \& PE CEE. Unfortunately, EVCA does not present any CEE data on VC and PE funds separately. But, in the author's opinion, the capital structure of VC and PE funds in CEE countries is not very significant differences, since, according to EVCA data, CEE market was more focused on the SEED and start-up stage investments, with the early stage investments constituting 74\% of total VC investments in CEE (EVCA Central and Eastern Europe Statistics, 2012). The results of comparison between the capital structure of VC \& PE funds in CEE countries and the Latvian VCF are presented in Table 3.

Table 3

CEE and Latvian Venture Capital Funds Raised by Type of Investors 2007-2011

\begin{tabular}{|c|c|c|c|c|c|c|c|c|}
\hline $\mathrm{Nr}$ & Types of investors & $\begin{array}{l}\text { CEE } 2007 \\
(\%)\end{array}$ & $\begin{array}{l}\text { CEE } 2008 \\
(\%)\end{array}$ & $\begin{array}{l}\text { CEE } 2009 \\
(\%)\end{array}$ & $\begin{array}{l}\text { CEE } 2010 \\
(\%)\end{array}$ & $\begin{array}{l}\text { CEE } 2011 \\
(\%)\end{array}$ & $\begin{array}{l}\text { CEE 2007-2011 } \\
\text { (average weighted \%) }\end{array}$ & $\begin{array}{l}\text { Latvian venture } \\
\text { capital funds } \\
\text { raised }(\%)\end{array}$ \\
\hline 1 & Government agencies & 2.6 & 2.7 & 28.3 & 64.3 & 14.1 & 9.6 & 65.14 \\
\hline 2 & Private individuals & 4.8 & 9.3 & 8.8 & 4.1 & 5.2 & 6.3 & 8.98 \\
\hline 3 & Corporate investors & 3.2 & 6.9 & 0.9 & 0.9 & 8.3 & 4.6 & 4.03 \\
\hline 4 & Banks & 7.6 & 12.1 & 10.1 & 1.6 & 12.2 & 9.1 & 3.64 \\
\hline 5 & Fund of funds & 21.2 & 25 & 9.4 & 8.3 & 25.6 & 21.3 & \\
\hline 6 & Pension funds & 8.7 & 18 & 0.8 & 0.7 & 12.7 & 10.9 & 18.2 \\
\hline 7 & Capital markets & No data & No data & No data & No data & No data & & 0 \\
\hline 8 & Insurance companies & 3.9 & 6 & 8.5 & 0 & 1.5 & 4.2 & 0 \\
\hline 9 & Family offices & No data & No data & No data & No data & No data & & 0 \\
\hline 10 & Other asset managers & 2.2 & 2.8 & 0.7 & 5.8 & 0.5 & 2.4 & 0 \\
\hline 11 & $\begin{array}{l}\text { Endowments and } \\
\text { foundations }\end{array}$ & No data & No data & No data & No data & No data & & 0 \\
\hline 12 & Sovereign wealth funds & No data & No data & No data & No data & No data & & 0 \\
\hline 13 & Academic institutions & No data & No data & No data & No data & No data & & 0 \\
\hline
\end{tabular}

Note. Source: Developed by the author, EVCA Central and Eastern Europe Statistics 2012; and the author's data (Latvian funds).

Analyzing the number of financing sources, it can be seen that, unlike five VCF sources in Latvia, CEE countries with VCF have available data on eight sources. Those three VCF sources in CEE which do not finance VCF in Latvia, are fund of funds, insurance companies, and other asset managers. If we consider CEE average data for five years, it will be seen that three sources (except for social capital), with fund of funds being 
the largest, jointly provide about 35\% of financing of CEE funds. In 2011, the share of the same sources had increased to 50.5\%. At the same time, the share of public financing has dropped below average and constituted $14.1 \%$. According to EVCA data, corporate investors showed interest towards buy-out funds, growth funds, and blend funds (EVCA Central and Eastern Europe Statistics, 2011). As regards VCF of Latvia, the share of financing retirement funds turned out to be 2.2 times as much as that in VCF CEE. As compared with Latvian VCF capital structure, the structure of attracted capital of VCF CEE is 2.4 times as large in terms of bank financing, but, at the same time, financing from government agencies is almost thrice smaller. If CEE government agencies' investment data for 2011 is compared with the respective Latvian data, then it will be obvious that the share of government agencies in Latvia is 4.6 times as large. It came to $65.1 \%$ of all the resources attracted by VCF of Latvia. In 2013, LGA had sponsored three more VCF to the amount of EUR 30M. Apart from that, one of the existing VCF of Latvia was additionally financed by social capital to the amount EUR 1.8M in 2013.

As a result, the share of government agencies in Latvian VCF reached 80\% early in 2014. Accordingly, the share of non-governmental investors of Latvian VCF had constituted 20\% as of the beginning 2014. According to EVCA data, government agencies remained to be the largest source of funds capital in CEE countries in 2012, providing for $29 \%$ of the total volume of attracted capital. Funds of funds were the second largest financing source (19\%), while retirement funds had invested 15\%. If financing sources are subdivided into internal and external ones, it will be seen that the drivers of internal financing sources in CEE countries were government-supported programs. European investors from outside of CEE region were the main financing source as before, having invested almost $60 \%$ from the total volume of attracted capital. The U.S. investors had provided $20 \%$. Local investors had invested $4 \%$, which attests to a deficiency of institutional investors in the region (EVCA Central and Eastern Europe Statistics, 2012). One of the reasons for the deficiency of internal VC in CEE countries may be an essential capital export. In Estonia for example, 69 projects out of 120 fund-financed ones were launched in Estonia, while the remaining 51, or $42.5 \%$ were launched abroad (EstVCA home page, 2013). In CEE countries, essential annual fluctuations of investor attraction volumes and structure are recorded. To a large extent, those fluctuations depend on a specific cycle the funds are in. The annual fluctuations must be taken into account when analyzing the structure of attracted resources. Unfortunately, EVCA publishes generalized data only; therefore, there is no opportunity for examining the situation with respect to individual small countries and in the context of financing stages, which would have given some additional information to be used in a more profound analysis. In the opinion of VCs - partners of Imprimatur Capital Fund Management company, Latvia is a market too small to be interesting to such capital sources as fund of funds and some global investors of the venture industry. The investigations show that one of the factors of attractiveness for VC are the market volume (Mrsik, Lazarevski, \& Smokvarski, 2012; Karsai,2012; Prohorovs, 2013a). For that reason, countries most attractive to VC among CEE are Poland, Hungary, Czech Republic, and Romania. This is confirmed by data of Global index of countries' attractiveness to VC (Groh, Liechtenstein, \& Lieser, 2012). It can be assumed that fund of funds is mainly investing exactly into VCF of the above-listed countries.

Let's consider the following example by analyzing the structure of the main investors of VC\&PE funds of Poland and compare them to indices of Latvia (see Table 4).

As it can be seen from Table 4, fund of funds dominates in VC\&PE funds-raising investor structure of Poland-25.9\%. The second-large source of capital was endowments and foundations-13.2\%. Governmental 
agencies whose share was $6.3 \%$ were only the fifth fund raising source in terms of importance. The comparison between the investor structure of Poland and Latvia, shows that, despite the two countries are members of CEE and EU 11, their structure (types) of investors and their specific weights of similar types of investors differ greatly. When a huge difference is estimated in foreign investor attraction indices in Poland and Latvia, a confirmation of the above-stated opinions of a number of researchers is obtained - namely, that the market size is of great importance to attract VC. The author believes that a small market confines investors' activities and, alongside with some other factors of (non)-attractiveness of $\mathrm{VC}$, may promote the outflow of domestic VC (Prohorovs, 2013b). Taking Estonia as an example, 69 projects out of 120 ones financed by funds were launched in Estonia, while the remaining 51 (or 42.5\%) were launched abroad (EstVCA home page, 2013).

For that reason, the Government of Latvia has to meet the capital demands of VC industry of Latvia in full or in part, thus, making up the deficiency of institutional investors-primarily, foreign ones. If Latvia had reached Poland's indices in terms of attraction of foreign venture capital, the capital volume of VC\&PE funds would increase almost thirtyfold.

Table 4

Comparison Between Share Percentages of the Main VC Funds-Raising Sources (Investor Types) of VC\&PE Funds of Poland and VCF of Latvia for 2007-2011 (Average Performance for Five Years Calculated)

\begin{tabular}{|c|c|c|c|c|c|c|c|c|}
\hline $\begin{array}{l}\text { Fund raising } \\
\text { sources }\end{array}$ & $\begin{array}{l}\text { Fund } \\
\text { funds }\end{array}$ & $\begin{array}{c}\text { of Endowments } \\
\text { foundations }\end{array}$ & $\begin{array}{c}\text { and Pension } \\
\text { funds }\end{array}$ & Banks & $\begin{array}{l}\text { Government } \\
\text { agencies }\end{array}$ & $\begin{array}{l}\text { Insurance } \\
\text { companies }\end{array}$ & $\begin{array}{l}\text { Private } \\
\text { individuals }\end{array}$ & $\begin{array}{l}\text { Domestic } \\
\text { sources }\end{array}$ \\
\hline $\begin{array}{l}\text { Poland } \\
\text { VC\&PE funds }\end{array}$ & 25.9 & 13.2 & 10.2 & 7.7 & 6.3 & 3.3 & 1.0 & 3.3 \\
\hline Latvian VCF & 0 & 0 & 18.2 & 3.6 & 65.1 & 0 & $8.98^{*}$ & $\begin{array}{l}\text { More, then } \\
95\end{array}$ \\
\hline
\end{tabular}

Notes. " Taking into account GPs investments (management partners). Source: Developed by the author, EVCA Central and Eastern Europe Statistics 2011 (Poland), author data (Latvia) and the author's calculation.

So far, there are not so many "exit" VCF and other success stories in CEE countries (and in Latvia, prospectively), while Chen, Gompers, Kovner, and Lerner (2010) and Prohorovs (2013a) believe that success story is an important factor governing the opening of new funds and affiliates and the investments into VCF. Bottazzi, Da Rin, and Hellmann (2008) believe as well that there exist some positive relationships between investors' activity and the success of portfolio companies. In the opinion of Schertler and Tykvova (2011), one of the factors influencing cross-border investments to small countries, is the investments magnitude (small sums are not interesting) and the availability of local partners - venture capitalists cooperating with foreign investors, as well as the international practice of those foreign-based VC (Schertler \& Tykvova, 2011). Moreover, Schertler and Tykvova (2012) consider that cross-border investments are influenced by such factors as tax, legal environment for $\mathrm{VC}$ and mediation and capitalization of stock market. The author believes that the last factor mentioned (capitalization of stock market) is one of the main factors hampering the attraction of foreign VC to Latvia. Cumming and Johan (2012) are of the same opinion; they believe that one of the two most popular "exits" among VC is the initial public share placement (IPO). They also believe that VCF take part in the first round of investments more reluctantly than they did before the crisis (Cumming \& Johan, 2012). This may explain and support the decisions by the governments of some CEE countries to sponsor VCF, funding the early stages of company development. At the same time, in the opinion of Pelly and Kramer-Eis (2011), social capital should not just be used as a VCF financing tool but should be a catalyst for the attraction of non-governmental investors and for creating a greater attractiveness for investors to finance exactly 
innovative projects (Pelly \& Kramer-Eis, 2011). Bottazzi et al. (2008) believe that investigators have so far underestimated the influence of human capital upon attracting VC investments.

After drawing the comparison between the Latvian VCF capital structure and VCF of Europe and CEE countries, the differences in capital structure of various VCF of Latvia will now be considered. The funds have been assigned reference numbers instead of their names to ensure confidentiality of information. Lack of fund name has impact on information quality. The data on capital structure of all the five VCF is shown in Table 5.

Table 5

Share Percentage of Various Investor Classes in VCF Capital of Latvia (\%)

\begin{tabular}{lccccc}
\hline $\begin{array}{l}\text { Fund/financing source (funds are stated } \\
\text { unnamed by reason of confidentiality) }\end{array}$ & Fund No 1 & Fund No 2 & Fund No 3 & Fund No 4 & Fund No 5 \\
\hline Government agencies & 100 & 67.0 & 64.2 & 66.6 & 33.3 \\
Private individuals & 0 & 5.8 & 26.1 & 3.3 & 0 \\
Corporate investors & 0 & 0 & 0 & 0 & 33.3 \\
Banks & 0 & 8.3 & 0 & 4.8 & 0 \\
Pension funds & 0 & 13.2 & 8.5 & 23.7 & 20.0 \\
Fund Management Company $^{*}$ & 0 & 5.5 & 1.0 & 1.3 & 13.3 \\
\hline
\end{tabular}

Notes. ${ }^{*}$ Capital source is not stated in the list of EF. Source: Developed by the author's data.

Considering the number of financing sources, not counting Fund Management Company as a separate source that might be attributed to investments of private individuals or corporate investors (if resources have been invested by the fund management company) - it is fair to say that the Latvian VCF capital structure has essential differences - first of all, in terms of financing sources. There is one fund with a sole investor-namely, government agencies. All of the VCF, except VCF wholly financed by government agencies, have managed to attract the capital of retirement funds as investors. Two funds have only three kinds (classes) of investors participating in capital and two more funds have four. If no government agencies are taken into account among those kinds of investors, it turns out that two VCF have only three classes of investors, and two more VCF have just two of them. Only one VCF has managed to attract corporate investors. The share percentage of private individuals or corporate investors fluctuates from 0 to $26.1 \%$ in various funds (not counting VCs shares), which is quite an essential fluctuation. The share of Fund Management Company fluctuates from $1.3 \%$ to $13.3 \%$ in various funds, leaving alone the fund where $100 \%$ of the capital were invested by government agencies. According to the data collected by the author, not less than $95 \%$ of VCF capital of Latvia was attracted from local investors. The share of domestic sources in CEE countries fluctuates from $8.3 \%$ to $36.5 \%$ annually, depending on social capital investment volumes for a specific year. At the same time, the share of domestic sources in Europe in general constitutes 34.3\% (EVCA Central and Eastern Europe Statistics, 2011). Based on this fact, one may come to the conclusion as follows: Either Latvia is very unattractive to foreign investors of VC or the Latvian VCF have failed to attract foreign investors for some other reasons. As an example, according to Y. Li, Vertinsky, and J. Li (2013), institutional and cultural distances exercise an essential negative impact on the attraction of international venture capital. In the opinion of Prohorovs (2013a), among the factors exercising a negative impact on the attraction of $\mathrm{VC}$, there may be absence of a neighbouring country with a strong VC industry in the vicinity of Latvia. The author called that factor a cross-border one (Prohorovs, 2013a). Moreover, one may agree with the EVCA conclusion that CEE countries lack institutional investors (EVCA Central and Eastern Europe Statistics, 2012). At the same time, the only Latvian PE fund 
registered as of the beginning of 2014-ABLV Private Equity Fund - has managed to raise EUR 10M from non-governmental sources in 2011 (ABLV, 2011). According to LVCA-issued data, the capital of ABLV Private Equity Fund constituted EUR 22M at the year-end 2013. This points either to the fact that not only state financing sources are ready to invest into the Latvian VC\&PE or to the fact that, with respect to private and institutional investors of capital, investments into PE funds are more important than those in VCF.

Having considered the structure of VCF financing sources, it would be logical to assume that, given a small number of investor classes, the size of VCF capital of Latvia will be small as well. In order not to divulge the information not stated in public space, the funds were assigned just reference numbers instead of their names. The sizes of VCF of Latvia are shown in Table 6.

Table 6

Sizes of VCF of Latvia

\begin{tabular}{|c|c|c|c|c|c|c|}
\hline $\begin{array}{l}\text { Fund (funds are stated } \\
\text { unnamed by reason of Fund No } 1 \\
\text { confidentiality) }\end{array}$ & Fund No 2 & Fund No 3 & Fund No 4 & Fund No 5 & $\begin{array}{l}\text { Total amount } \\
\text { (thousand EUR) }\end{array}$ & Average \\
\hline $\begin{array}{l}\text { Fund size (in thousand } 6,000 \\
\text { EUR) }\end{array}$ & 4,500 & 7,000 & 30,000 & $6,532.4$ & $54,032.4$ & 10,806 \\
\hline
\end{tabular}

Note. Source: Developed by the author's data.

The average size of VCF of Latvia is EUR 10.8M, which makes 39.4\% from the average size of VC\&PE funds in CEE in 2011 (EUR 27.3M). The average size of CEE funds has increased by $40 \%$ since 2010 (EVCA Central and Eastern Europe Statistics, 2011). The average size of VCF of Europe in 2010 (final closing in the year) was EUR 43.2M, in 2011-57.7M, and in 2012-EUR 49.7M (EVCA, 2013). In the second half of 2013 in Latvia, three new funds each amounting to EUR 10.5M have occurred as a result of a tender held in Latvia, financially supported by LGA ${ }^{1}$. Their size was almost equal to the average size of the existing VCF (EUR $10.5 \mathrm{M}$ with each of the funds, including EUR $0.5 \mathrm{M}$ that had to be provided by a private management company); therefore, the average size of Latvian VCF has not changed as of the beginning of 2014. Significantly, as many as 14 private management companies pretended to the right of controlling those VCF. The majority of them were established exceptionally for the purpose of taking part in the tender with a view of acquiring entitlement to control those three new VCF.

The NESTA experts in their report "UK Government support for early-stage venture capital research" come to the conclusion that the size of hybrid VCF (a hybrid fund is VCF with social capital taking part) should be not less than $£ 50 \mathrm{M}$. Lesser hybrid funds of $\mathrm{VC}$ cannot diversify their portfolios and ensure the subsequent financing for the most prospective investments (contained in their portfolios). As regards VCF of early-stage financing, it must be capable of controlling a diversified portfolio (at least 20 enterprises) and ensure funding of a few rounds of financing necessary for a successful exit (NESTA, 2009). Dębski (2010) believes that the main problem faced by VC market of Poland is still a small size of VCF. At the same time, Cumming and Dai (2011) believe that, given the excessive growth of the size of $\mathrm{VC}$ and $\mathrm{PE}$ funds, the quality of human capital may be lost and its deficiency may be manifested. According to the opinion of Cumming and Johan (2008) with regard to Pre-Seed Fund government venture capital programs, the impact of government venture funds depends not only on program structure but on the selection of managers who make investments (Cumming \& Johan, 2008).

\footnotetext{
${ }^{1}$ Latvian private equity and venture capital association home page (Retrieved from Latvian private equity and venture capital association home page) and Latvijas Garantiju aǵentūra home page (Retrieved from www.lga.lv).
} 
Tykvová et al. (2012) also emphasize a small number of VCF of sufficient size in Europe that would have experienced partners, skilled in the area of venture investments. According to the data from Snieska and Venckuviene (2011), three hybrid VCF operate in Lithuania, with the smallest of them being Business Angels Co-investment Fund possessing the capital of EUR 8.4M, while the average capital of the three VCF is EUR 16.1M. In fact, the average size of hybrid VCF in Lithuania exceeds the average size of VCF in Latvia by $50 \%$.

Let's compare between the size of VCF of Latvia and Ireland - a small country like Latvia which had obtained international financial support during the crisis, just like Latvia did. The average size of 10 hybrid VCF of Ireland late in 2012 constituted EUR 56.9M. Four of the 10 VCF of Ireland specialize in SEED financing. The average size of hybrid VCF of Ireland made EUR 31M, while the minimum size was EUR 17M. The average size of investments of SEED funds in Ireland had constituted EUR 230,000 in 2012 (Enterprise Ireland, 2013). The average amount of 18 investments of a sole dedicated SEED fund Imprimature Capital in Latvia made EUR 107,000, while the average amount of investments in the start-up VCF Imprimature Capital Technology projects constituted EUR 383,000 and the average amount of 10 later-stage VCF BaltCap investments constituted EUR $1.132 \mathrm{M}^{2}$. The average amount of seed-stage investments constituted EUR 123,000, and that of start-up stage - EUR 673,000 Estonian Development Fund (EDF) (Kitsing, 2013). NESTA experts believe that the VCF should be ready to ensure the financing of the next rounds of the most prospective projects (if it turned to be impossible to find another investor or attraction of another investor is not expedient); at the same time, not less than 20 projects should be in the fund portfolio to ensure diversification (NESTA, 2009). To provide for innovation-driven growth, realize the National Development Plan for 2014-2020 and, furnish young innovative companies in high-tech sectors (such as Biotech, Energy, ICT manufacturing Internet, Nanotech, Other R\&D, Pharmaceutical, Robotics, Software, TLC and Web publishing) with finance and "smart capital", the size of VCF of Latvia should be essentially larger than it currently is.

Briefly summarizing this study, one may agree with Da Rin, Nicodano, and Sembenelli (2006), that a reasonable State policy should use a wider range of tools to promote $\mathrm{VC}$ than merely directing more public funds in VCF (Da Rin, Nicodano, \& Sembenelli, 2006).

\section{Conclusion and Recommendations}

From all above-mentioned paper, we can conclude that:

(1) There exist various forms and methods of direct and indirect governmental promotion of VCF in various countries.

(2) Direct governmental promotion of VCF has a number of advantages and shortcomings subject to a lot of various factors, including macro-economic situation, the maturity of $\mathrm{VC}$ system, and capital markets.

(3) Despite the advent of the post-crisis period and the general macroeconomic stabilization on a global scale, the early-stage VC investors demonstrate an abrupt downward trend of fund raising - both in absolute terms and in the share of early-stage VCF fund raising with respect to the whole VC\&PE industry.

(4) EVCA statistics shows VCF investor structure, which provides an opportunity of analyzing VCF structure and comparing it to similar statistics in another country; however, VCF have not been singled out in EVCA statistics published in Special Paper Edited by the EVCA Central and Eastern Europe Task Force. Due to this, one can not analyze the difference in VCF fund-raising structure between European and CEE countries

\footnotetext{
${ }^{2}$ Retrieved from www.lga.lv.
} 
or between CEE countries and a specific country; as a result, a more generalized comparison (between all kinds of funds) has to be made. This makes such investigations of CEE countries less informative (in the framework of the impossibility of comparison between capital sources with respect to different VC\&PE funds). Since VC fund raising is utterly obstructed with respect to the earliest stages of financing, it would be expedient for EVCA to collect and publish statistical data on each of the financing stages and possible on separate countries, which would allow one to compare fund raising results and VC promotion tools in specific countries.

(5) VCF capital structure in terms of investor types and the share of foreign VC vary considerably among various CEE countries. It can be assumed that the structure of VCF capital and the share of foreign VC in specific countries largely depends on the size of the economy of the country.

(6) The number of financing sources (types of investors) of VCF in Latvia is almost three times less than in VCF of Europe.

(7) The share of domestic investors in Latvian VCF is very high- $95 \%$ (in CEE countries, it ranges from $8.3 \%$ to $36.5 \%$, while in Europe the average is $34.3 \%$ ), which suggests a possible unattractiveness of the country for foreign $\mathrm{VC}$ or inability to attract foreign investors in $\mathrm{VC}$.

(8) As of the beginning of 2013, the share of public capital in VCF of Latvia was $65.1 \%$, and at the beginning of 2014, it amounted to 76.2\% (the share of public capital in VC \& PE funds in CEE countries generally ranges from 6.1 to $58.5 \%$ ).

(9) The share of Fund Management Company in Latvian VCF on average is 3.1\% of the capital funds.

(10) All the eight (8) VCF of Latvia are hybrid funds, which means insufficiency and immaturity of private $\mathrm{VC}$ and institutional investors in $\mathrm{VC}$, as well as that investments in Latvia may be less attractive for potential private investors in $\mathrm{VC}$ and private VCF.

(11) The average size of VCF of Latvia constitutes EUR 10M, which is much smaller in size as compared to VCF of Europe, CEE countries, the hybrid VCF of Lithuania and Ireland examined by us, and the opinions of experts on the necessary sizes of hybrid VCF.

\section{Practical Usefulness of the Study}

(1) This study can be used by institutions of EU, as well as state institutions and development institutes, public funds of VC funds of individual countries, especially CEE and others, passing or having passed the way of transitive economy - for the analysis and formation of public policy in the field of capital raising into VCF.

(2) This study can be used by EVCA, VC \& PE associations of different countries, especially CEE countries - both in the form of statistical and analytical material and as a material to establish an attitude towards hybrid VCF and governmental forms of promotion of VC investments.

(3) This study can be used by the Ministry of Finance of Latvia and the Ministry of Economics of Latvia as institutions responsible for the implementation of innovative economy-financing programs and the alternative financial tools, and by the Latvian Investment and Development Agency and the Latvian Agency for guarantees (the public fund of VC funds) for the formation and implementation of Latvian policy of financing of innovation-driven growth, and for working out the most effective tools to promote the development of VC industry in the medium and the long run.

(4) One can hope that this study has filled the information vacuum for VC researchers and practitioners to a certain extent, which opens up interesting possibilities for further research of VC. 


\section{References}

ABLV annual report. (2011). Retrieved from http://www.ablv.lu/content/1/9/0/7/9/e0b27e84/ablv_AR_2011_en.pdf

Bertoni, F., \& Tykvová, T. (2012). Which form of venture capital is most supportive of innovation? Retrieved from http://ftp.zew.de/pub/zew-docs/dp/dp12018.pdf

Bertoni, F., Colombo, M. G., \& Quas, A. (2011). Patterns of venture capital investments in Europe. Retrieved from https://www.google.lv/search?q=Bertoni\%2C+F.\%2C+Colombo\%2C+M.G.+and+A.+Quas+(2011).+Patterns+of+venture+c apital+investments+in+Europe. + SSRN+Working + paper+No.+1920351.\&oq=Bertoni\%2C+F.\%2C+Colombo\%2C + M.G. + an d+A.+Quas+(2011).+Patterns+of+venture+capital+investments+in+Europe.+SSRN+Working +paper+No.+1920351.\&aqs $=\mathrm{c}$ hrome..69i57.2832j0j8\&sourceid=chrome\&espv=210\&es_sm=122\&ie=UTF-8

Bottazzi, L., Da Rin, M., \& Hellmann, T. (2008). Who are the active investors? Evidence from venture capital. Journal of Financial Economics, 89, 488-512.

Brander, J., Du, Q., \& Hellmann, T. (2010). The effects of government-sponsored venture capital: International evidence. Retrieved from http://sites.kauffman.org/efic/conference/BranderDuHellmannJune9th2010.pdf

Brander, J., Egan, E., \& Hellmann, T. (2010). Government sponsored versus private venture capital: Canadian evidence. Retrieved from http://www.nber.org/papers/w14029.pdf?new_window=1

Chen, H., Gompers, P., Kovner, A., \& Lerner, J. (2010). Buy local? The geography of successful and unsuccessful venture capital expansion. Journal of Urban Economics, 67, 90-102.

Cincera, M., \& Veugelersb, R. (2013). Exploring Europe's R\&D deficit relative to the US: Differences in the rates of return to $R \& D$ of young leading $R \& D$ firms. Retrieved from http://www.solvay.edu/sites/upload/files/P._Dekie/WP_001-2013.pdf

Cumming, D., \& Dai, N. (2011). Fund size, limited attention and valuation of venture capital backed firms. Journal of Empirical Finance , 18, 2-15.

Cumming, D., \& Johan, S. (2009). Pre-seed government venture capital funds. Journal of International Entrepreneurship, 7(1), 26-56.

Cumming, D., \& Johan, S. (2012). Is venture capital in crisis? Retrieved from http://www.worldfinancialreview.com/?p=2122

Cumming, D., Grillib, L., \& Murtinu, S. (2013). Governmental and independent venture capital investments in Europe: A firm-level performance analysis. Retrieved from http://emma.polimi.it/emma/events/eventAiIG/attachments/2.4\%20grilli\%20murtinu\%20cumming_governmental\%20and $\% 2$ 0independent $\% 20$ venture\%20capital.pdf

Da Rin, M., Nicodano, G., \& Sembenelli, A. (2006). Public policy and the creation of active venture capital markets. Journal of Public Economics, 90(8-9), 1699-1723.

Dębski, W. (2010). PE/VC sector in Poland between 2005 and 2008 . Retrieved from http://journaldatabase.org/articles/pe_vc_sector_poland_between_2005_20081.html

Enterprise Ireland. (2013). Seed and venture capital programme 2012 report. Retrieved from http://www.enterprise-ireland.com/EI_Corporate/en/Publications/Reports-Published-Strategies/SVC-2012-Report.pdf

Estonian Development Fund home page. (2014). Retrieved from http://www.arengufond.ee/en/arengufondist/tutvustus/

EstVCA home page. (2013). Statistika in EstVCA: Database online. Retrieved from http://www.estvca.ee/estvcast/statistika

European Commission, European Union Support Programmes for SMEs, An overview of the main funding opportunities $\begin{array}{llllll}\text { available } & \text { to } & \text { European } & \text { SMEs. } & \text { (2012). } & \text { Retrieved from }\end{array}$ http://ec.europa.eu/enterprise/newsroom/cf/_getdocument.cfm?doc_id=7264

EVCA Central and Eastern Europe Statistics. (2011). An EVCA special paper edited by the EVCA Central and Eastern Europe task force. Retrieved from http://www.evca.eu/publications/PBCEE11.pdf

EVCA Central and Eastern Europe Statistics. (2012). An EVCA special paper edited by the EVCA Central and Eastern Europe task force, July 2013. Retrieved from http://www.evca.eu/publications/PBCEE12.pdf

EVCA

Poland.

(2011).

Retrieved

from http://www.psik.org.pl/data/items/polish-private-equityventure-capital-market-in-2011.html

EVCA Yearbook. (2012). Activity data on fundraising, investments and divestments by private equity and venture capital firms in Europe. Retrieved from http://www.evca.eu/uploadedfiles/home/press_room/Yearbook_2012_Presentation_all.pdf

EVCA Yearbook. (2013). European Private Equity \& Venture Capital Association report based on PEREP analytics data, 2013. Retrieved from http://www.evca.eu/research/activity-data/annual-activity-statistics/ 
Financial News. (2012). Lobby groups have a strong showing as the buyout industry seeks to rebuild its reputation. Retrieved from http://www.efinancialnews.com/story/2012-07-09/fn100-2012-private-equity

Fund Structures for Angel Funds and Early Stage/Seed Venture Funds, Angel Blog. (2013). Retrieved from http://www.angelblog.net/Fund_Structures.html

Gadus, V. (2012). Government venture funds. Retrieved from http://arno.uvt.nl/show.cgi?fid=128478

Ghalbouni, D., \& Rousies, D. (2010). Venture capital: A big shake. Harvard Business Review, 10(62), 19-22.

Grilli, L., \& Murtinu, S. (2013). Government, venture capital and the growth of European high-tech entrepreneurial firms. Retrieved from http://ssrn.com/abstract=2066867

Groh, A. (2010). The capital flow from institutional investors to entrepreneurs. Retrieved from http://papers.ssrn.com/sol3/papers.cfm?abstract_id=1547791

Groh, A., Liechtenstein, H., \& Lieser, K. (2012). The global venture capital and private equity country attractiveness index-2012 annual.

Retrieved

from http://www.preqin.com/docs/reports/IESE_Global_VC_and_PE_Country_Attractiveness_Index_2012.pdf

Guellmann, P. (2013). The German private equity market: Recent trends and outlook. Proceedings from 4th Annual German M\&A and Private Equity Forum. Duesseldorf.

Hall, B. H., \& Lerner, J. (2010). The financing of R\&D and innovation. Handbook of the Economics of Innovation.

Humphery-Jenner, M. (2012). Stimulating venture activity through government investment in venture funds. European Business Organization Law Review, 13(1), 103-124.

Jääskeläinen, M., Maula, M., \& Murray, G. (2007). Profit distribution and compensation structures in publicly and privately funded hybrid venture capital funds. Elsevier Science, Research Policy, 36(7), 913-929.

Jakušonoka, I., \& Prohorovs, A. (2011). Economic science for rural development. Proceedings from the International Scientific Conference, No. 25. Jelgava: LLU.

Karsai, J. (2011). The 2011 results of the private equity and venture capital industry. Retrieved from http://www.hvca.hu/wp-content/uploads/2011/12/the-2011-results-of-the-private-equity-and-venture-capital-industry.pdf

Karsai, J. (2012). Development of the hungarian venture capital and private equity industry over the past two dekades. Retrieved from http://econ.core.hu/file/download/mtdp/MTDP1201.pdf

Kitsing, M. (2013). Government as a venture capitalist: Evidence from Estonia. Proceedings from Industry Studies Association Annual Conference.

Lerner, J. (2010). Innovation, entrepreneurship and financial market cycles. Retrieved from http://www.oecd.org/science/inno/44840087.pdf

Lerner, J., \& Tåg, J. (2012). Institutions and venture capital. Stockholm, Sweden: Research Institute of Industrial Economics.

Li, Y., Vertinsky, I. B., \& Li, J. (2013). National distances, international experience, and venture capital investment performance. Journal of Business Venturing, 29(4), 471-489.

Luukkonen, T., Deschryvere, M., \& Bertoni, F. (2013). The value added by government venture capital funds compared with independent venture capital funds. Technovation, 33(4-5), 154-162.

Mason, C., Botelho, T., \& Harrison, R. (2013). The transformation of the business angel market: Evidence from Scotland. Retrieved from http://www.gla.ac.uk/schools/business/staff/colinmason/\#tabs=1

Meyer, T. (2007). The public sector's role in the promotion of venture capital markets. Retrieved from http://papers.ssrn.com/sol3/papers.cfm?abstract_id=1019988

Mrsik, J., Lazarevski, D., \& Smokvarski, E. (2012). Evolution of the venture capital financing for growing small and medium enterprises in Central and Eastern Europe countries: The case of Macedonia. Retrieved from http://mpra.ub.uni-muenchen.de/41997/

NESTA. (2009). From funding gaps to thin markets: UK government support for early-stage venture capital. Retrieved from http://www.nesta.org.uk

Pelly, R., \& Kramer-Eis, H. (2011). Creating a better business environment for financing business, innovation and green growth. Retrieved from http://www.oecd.org/pensions/private-pensions/48621154.pdf

Perez, C. (2012). Financial bubbles, crises and the role of government in unleashing golden ages. FINNOV Discussion Paper, Work package 2 .

Prohorovs, A. (2013a). Economic science for rural development 2013. Retrieved from http://connection.ebscohost.com/c/articles/87566454/attraction-investments-venture-capital-private-equityfunds-latvia 
Prohorovs, A. (2013b). The problem of capital attraction into venture capital funds of Latvia. Journal of Business Management, 7 , $16-41$.

Prohorovs, A. (2014). Quantitative and qualitative analysis of the informal venture capital in Latvia. Journal Economics and Rural Development, 10(1), 47-68.

Prohorovs, A., \& Jakušonoka, I. (2012). Problems and tendencies of venture capital: A critical analysis. Proceedings from the International Scientific Conference. Riga.

Prohorovs, A., \& Pavlyuk, D. (2013). Analysis of economic factors influencing venture capital investment in European countries. Socialiniai tyrimai/Social Research, 4(33), 111-118.

Sahlman, A. W., \& Richardson, E. (2010). The changing face of angel investing. Retrieved from http://www.hbs.edu/faculty/Pages/item.aspx?num=39674

Schertler, A., \& Tykvova, T. (2011). Venture capital and internationalization. International Business Review, 20, $423-439$.

Schertler, A., \& Tykvova, T. (2012). What lures cross-border venture capital inflows? Journal of International Money and Finance, 31, 1777-1799.

Schröder, C. (2009). Financial system and innovations-determinants of early stage venture capital in Europe. Retrieved from http://d-nb.info/993775322/34

Snieska, V., \& Venckuviene, V. (2011). Hybrid venture capital funds in Lithuania: Motives, factors and present state of development. Inzinerine Ekonomika-Engineering Economics, Kaunas University of Technology, 22(2), 157-164

Snieska, V., \& Venckuviene, V. (2012). The rationality for government sponsored venture capital funds in Lithuania: Innovation perspective. Economics and Management, 17(1), 230-236.

Tykvová, T., Borell, M., \& Kroencke, T. A. (2012). Potential of venture capital in the European Union. Retrieved from http://www.europarl.europa.eu/studies

Veugelers, R. (2011). Mind Europe's early-stage equity gap. Retrieved from http://ec.europa.eu/research/innovation-union/pdf/expert-groups/i4g-reports/i4g_policy_brief_4_-_financing_innovation.pdf

VICO. (2011). Venture capital: Policy lessons from the VICO project. Retrieved from http://www.vicoproject.org/doc/policy/VICO_FinalPolicyBrief.pdf

Zarutskie, R. (2006). Do venture capitalists affect investment performance? Evidence from first-time funds, 2006. Retrieved from http://www.lse.ac.uk/fmg/research/RICAFE/pdf/Zarutskie_Rebecca.pdf 